\title{
A PRAGMATIC APPROACH TO THE ANALYSIS OF MARKETING ADAPTATION TO RUSSIAN NATIONAL CULTURE
}

\author{
Anna N. Tikhomirova \\ China University of Geosciences (Wuhan, China) \\ anna_tikhomirova@live.ru
}

\begin{abstract}
There are a great number of transnational corporations operating all over the world. All of them are facing the issue of national culture, and cross-cultural difference is of vital importance. Choosing appropriate marketing strategy assures success or failure on the international market. The concept of culture is very dynamic and requires constant observation. The tasks marketing managers started to deal with became more complex, requiring cultural sensitivity and ability to overcome cross-cultural differences.

The research, presented in this paper, attempts to analyze whether national culture affects marketing strategy of international companies. The framework of cultural dimensions developed by Hofstede was taken as a basis for the analysis of Russian national culture. The author resorts to the quantitative approach based on the conducted survey and analyzes data collected in the Russian Federation. At first cultural values were used to identify Russia. Cultural values were measured at the individual level and compared to the previous findings on Russian culture. Analysis of differences in cultural values on the individual level among Russian population has shown that there is some kind of difference between previous findings related to Russia and findings obtained during the research. The level of adaptation was evaluated from the consumers' point of view. Questionnaire was designed based on the analyzed literature, and obtained data was statistically analyzed with SPSS. Linear regression and correlation analysis were used to prove the hypotheses of the research work. Though Russian national culture was depicted as unique with a great number of peculiarities, in the industries, analyzed in this paper, the connection between marketing strategy adaptation and uncertainty avoidance, and marketing strategy adaptation and dimension of collectivism for fast moving consumer goods was proved statistically.

The second stage of the research included the analysis of the empirical evidence of the cultural adaptation of the advertisement of fast moving consumer goods for the Russian consumer. A number of samples were analyzed, and two cases are presented in the paper. The pragmatic approach was used for the analysis of the empirical data.

The results of the study add to the theoretical knowledge about the relationship between cultural dimensions in Russia and marketing strategies employed by transnational companies. They also contribute to the knowledge about Russian consumers' behavior patterns. The framework can be potentially applied to other spheres of professional business in Russia.

Key words: cross-cultural differences, professional communication, marketing strategy, rhetoric, national culture, pragmatics, discourse of advertising.
\end{abstract}

\section{INTRODUCTION}

Modern world is globalized. Transnational corporations are playing the leading role in the economical development of the world. Globalization changes occur primarily under the influence of tough competition.

Transnational corporations are using all the possible tools and sources in order to gain competitive advantage. One of these tools is modern and effective marketing. Normally companies' strategy is based on the principles of international marketing, taking into consideration problems of cross-cultural heterogeneity. While developing an approach to the new market place international companies have to choose between two basic strategies: 
standardization or customization (or adaptation). When choosing a strategy, the company is paying attention to a number of factors where local culture is one of the crucial aspect.

Based on Hill's determinants of culture, cultural norms and value systems comprise a number of components: religion, social structure, education, political philosophy, economic philosophy and the language [Hill, 2007]. Marketing strategy is influenced by consumers' behavior, which in its way is affected by values, demographics, nonverbal communication and language.

In marketing discourse proper combination of language tools is one of the keys to the success of the campaign. The current research paper aims to analyze what language tools are used by the marketer in order to create an attractive image of the product.

The examined literature gives a wide range of researches on the topic of marketing from the perspective of the cross-cultural approach. Though the amount of works is large, at the same time the majority of works in this sphere are devoted to the analysis of the European and American markets. In current research the Russia Federation was chosen as a region of interest. Existing theoretical works don't pay enough attention to different aspects of cross-cultural marketing strategies and their application in the region of research interest. It's of great importance to figure out what aspects of marketing strategies are influenced by culture and how these aspects are perceived by consumers in the Russian Federation.

As the number of transnational companies (TNCs) operating all over the world is great, it seems necessary to narrow the field of analysis to one particular industry. Fast moving consumer goods (FMCG) industry was chosen as an object for the analysis. FMCGs form a large part of consumers' basket of goods over the world. Consumers as well as policy makers pay a lot of attention to the supply of FMCG to households because a retail sector of this particular industry is essential for daily provision of these essential goods at high quality and low cost [Majumdar, 2004; Brierley, 2002].

The object of the current research is FMCG in Russia.

The area of the research is professional marketing discourse in FMCG area.

Research question is "How Russian national culture is reflected in FMCG marketing discourse?".

In order to answer the research question the following objectives were pointed out:

1. To assess Russian national culture using CVScale at the individual level;

2. To assess customers' attitude towards standardization strategy;

3. To analyze which dimensions of Russian national culture are of particular importance for marketers in FMCG sphere;

4. To analyze marketing discourse using pragmatic approach.

\section{THEORETICAL BACKGROUND}

\subsection{Consumer culture}

American anthropologist and cross-cultural researcher Edward T. Hall defines culture as the way of life of a people, or the sum of their learned behavior patterns, attitudes or material things [Hall, 1976]. The idea that culture is a learned set of human behavior patterns and not given by nature is supported by Lustig and Koester who define culture as - a learned set of shared interpretations about beliefs, values, norms and social practices, which affect the behaviors of a relatively large group of people [Lustig \& Koester, 2010]. 
There are many definitions of the concept of culture and many of these tend to focus on culture as a collective whole and less on the individual perceptions. Within the context of marketing, factors such as age, gender, nationality, work style, social status, wealth and language influence the way an individual sees and judges the world, thus should also be taken into consideration when planning marketing activities [Dake, 1991].

Kotler defines culture as the fundamental determinant of a person's desires and behavior [Kotler \& Keller, 2009].

This research work is based on the so-called classical cross-cultural theory: Hofstede's cultural dimensions. It represents a framework for cross-cultural communication which over time has been applied in different scientific disciplines such as general business and management.

Hofstede's cultural dimension model is a widely applied and validated approach to studying cultural values $(1984,1991,2001)$. He defines culture as a broad, collective pattern of cognitions, affects and actions that have important consequences for the functioning of societies, of groups within those societies and of individual members of such groups [Hofstede, 2001].

The model consists of six dimensions. From the viewpoint of consumers' behavior they can be interpreted in the following way [Mooij \& Hofstede, 2002]:

1. The power distance dimension. In large power distance cultures social hierarchy is of vital importance, every member of the society has his or her place. This dimension helps to understand which role global brands and luxury goods are playing. In cultures with a large power distance index it is important to show one's social status so that it would be clear for others. Global brands fulfill this function. Luxury articles, some alcoholic beverages and fashion items typically appeal to social status needs.

2. The difference between individualism/collectivism. In the sales process in individualistic nations, individuals need to get to the goal fast, while in collectivistic nations it is essential to first form a relationship and confidence between individuals. This alteration is revealed in the different roles of advertising: persuasion versus creating trust.

3. The masculinity/femininity dimension. In masculine cultures, performance and success are significant; and success must be established, so status brands or goods such as jewelry are vital to show one's achievement.

4. Uncertainty avoidance. High uncertainty avoidance nations have an inactive approach to healthiness by concentrating on pureness in food and drink and using more medicine, low uncertainty avoidance nations have a more active approach to health by concentrating on fitness and sports.

5. Long- versus short-term orientation. Values comprised in long-term orientation are persistence, ordering relationships by status, thrift, and having a sense of shame. The opposite thing is the short-term orientation, which comprises personal stability and solidity, and respect for custom.

Cultural aspects have been recognized as the ones influencing international marketing communications and success of marketing campaigns launched. Such aspects as language, values, customs, mindsets, traditions or religion arise and they should guide marketers while developing international marketing communications strategy.

The cultural values of the society, consumer behavior and marketing strategies are closely connected. Marketing incentives (the attributes of product, price, distribution, and promotion) reflect cultural values (abstract and non-abstract). They have influence on 
consumers and are used as means of realization of the goals, motives and models of consumer behavior.

\subsection{Russian consumer culture}

Cultural and marketing research gives the ground to think that Russians people prefer to consume international brands, expecting for them to be of higher quality. Consumers have a certain picture in their mind correlating the country with some cliché characteristics. At the same time there is a common belief among the Russian population that foreign markets import into Russia goods of poor quality compared to the original. A lot of Russian consumers prefer domestic brands of foodstuffs and drinks, having a strong belief that Russian foods are more genuine and contain smaller amounts of preservatives. At the same time, they regularly doubt the quality of these same local brands. These contradictory standpoints put Russian customers, and those firms marketing to them, in difficult circumstances.

According to Hofstede's findings, Russian national culture has the following characteristics: Power distance 93, Masculinity 36, Uncertainty avoidance 95, Long Term Orientation 81, Indulgence 20 [What about Russia?, http].

\subsection{Pragmatics in marketing discourse}

Linguistic pragmatics is defined, for the purposes of this paper, as the science of language use. It roots in linguistics, psychology, anthropology, and especially semiotics and the philosophy of language [Verschueren, 2015].

Linguistic pragmatics considers the functional aspect of how words and phrases are used, famously coined in the Wittgensteinian expression 'the meaning of a word is its use in the language'.

Firstly, the main unit of pragmatic analysis is the sentential utterance rather than the word - focusing on the whole rather than the part. Secondly, a pragmatic treatment of meaning needs to be attentive towards not only the utterance itself, but also the situational context in which it is made, e.g. who is speaking, who is listening, what conventions exist, what sequence utterances are made in, what effects utterances produce, and so on. Thirdly, definitional meanings can be understood not only as compositions of atomic parts - a series of denotations - but also only as codifications of conventions - a bundle of connotations, associations and cultural practices. Fourthly, an utterance can be understood simultaneously at variegated, multi-dimensional levels of abstraction - as a direct assertion, a move in a dialogical sequence, a tactical move in a language game, or an act which conforms to social norms and conventions [Magee, 2011].

Advertising discourse is the result of the lucky meeting of the iconic message with the textual one, so that image and text may go together and touch the soul of the consumer making $\mathrm{him} /$ her decide to buy the respective promoted product or service. The concept of discourse cohesion assures the compatibility between the image and the text within an advertisement [White, 2000].

Specialists have revealed that the language of advertising should be accessible for every single consumer to be able to properly understand the message in order to react in an proper way (namely, go and purchase the promoted product). The message should also be short: whether it is transmitted via TV or radio, it should not last more than 30 seconds [Condry, 
2010]. The slogan is supposed to have no more than 12 words, while the body text is necessary only under certain conditions: whether the promoted product belongs to the category of products for which the public shows a high degree of involvement [Bonnange \& Chantal, 2010; Goddard, 2002].

The art of writing an efficient sample of advertising discourse may be decisive for consumers when they are about to choose among more similar products.

As far as we see, in order to be efficient (namely, to sell the product), advertising discourse should take into consideration the following: the type of targets it addresses to; the age of the promoted product; the specific cultural features of the community which will get the promoted product.

A good advertisement is not necessarily an artistically written one, with a sophisticated textual message and an exquisite iconic one, but that very advert which will sell the promoted product. That is why it has to "speak" the language of the target, address those specific needs of the consumer which are to be fulfilled [Bălănescu, 2014].

\section{METHODOLOGY}

The current research comprises quantitative data analysis and empirical research.

On the stage of quantitative data analysis, the CVSCALE was adopted in order to analyze consumers' culture at the individual level. Self-completion questionnaire was chosen as a tool for primary data collection. While designing the survey questionnaire based on the examined theoretical base, it was decided that the questionnaire will consist of several parts. Multi-item Likert scales are common and the recommended question format for measuring latent consumer behaviour constructs such as attitudes, beliefs and values [Wong, Rindfleisch $\&$ Burroughs, 2003]. The questionnaire includes items measured with 5-point strongly agree to strongly disagree Likert scales. Due to the central role of cultural values to this research and to the difficulties in operationalization of the concept of culture, this variable has been an object of very special attention and exhaustive search for existing measures in scientific literature. The CVSCALE is a previously developed valid and reliable instrument which was adopted for the research [Naveen \& Yoo, 1998]. This instrument includes 26 items to measure the five cultural dimensions, with advantages of applicability to general consumer situations, adequate psychometric properties, and use in previous studies [Naveen \& Yoo, 1998; Lenartowicz \& Roth, 1999]. Therefore, this instrument was used to measure cultural values at the individual level.

Next part of the questionnaire represents the attitude towards FMCG marketing strategy. In this part a product is used as a mediator factor taking into consideration cultural dimensions. This part of questionnaire is based on previous research works and helps us analyze customers' perception of the degree of adaptation of the product. In this part we refer to the STRATADAPT scale developed by Lages, Abrantes and Lages [Lages, Abrantes \& Lages, 2008] and adapted by Morgan, Kaleka, and Katsikeas [Morgan, Kalekam \& Katsikeas, 2004]. This scale helps to analyze the degree of adaptation. The collected data were summarized and statistically analyzed by means of SPSS.

\section{The description of the questionnaire}

The questionnaire starts with some descriptive information. Part one contains four questions giving an overview image of the respondents. The questions concern age, gender, level of education and income. The questionnaire was completed by 175 respondents who are citizens of the Russian Federation. In terms of statistics, there were $65.7 \%$ of respondents in 
the age range from 18 to $30,20 \%$ at the age of 30 to $40,8.6 \%$ at the age of 40 to 50 and $5.7 \%$ at the age above 50. The table below represents the summary data on the age of the respondents.

The analysis of gender variable has shown that out of 175 questionnaires conducted, 170 are valid and 5 contain missing value. The majority of the respondents (54.3\%) are female and $42.9 \%$ are male.

The income was analyzed, giving four possible options. The majority of respondents (51.4\%) have income between 10000 and 30000 rubles, then comes income from 30000 to 60000 rubles $(31.4 \%$ ). 9.4\% have income lower than 10000 rubles, and there were no respondents with income over 60000 rubles. This can be explained by the fact that $65.7 \%$ of respondents are young people at the beginning of their career.

When it comes to education, out of 175 respondents 140 are graduate students (80\%), 10 respondents or $5.7 \%$ have only basic primary education, $11.4 \%$ have secondary school education.

Part 4 of the questionnaire, which is related to the purchase of household appliances, includes two questions with descriptive information. The first is related to the ownership of the household appliances which showed that $100 \%$ of respondents owe household appliances.

The second question was related to the usage of international brands of household appliances which also showed that $100 \%$ of respondents use household appliances produced by international brands.

The summarized information about respondents is represented in the table.

\begin{tabular}{|c|c|c|c|}
\hline & & Number & Percent (\%) \\
\hline Age & $\begin{array}{l}\text { from } 18 \text { to } 30 \\
\text { from } 30 \text { to } 40 \\
\text { from } 40 \text { to } 50 \\
\text { above } 50 \\
\text { Total }\end{array}$ & $\begin{array}{l}115 \\
35 \\
15 \\
10 \\
175\end{array}$ & $\begin{array}{l}65,7 \\
20,0 \\
8,6 \\
5,7 \\
100\end{array}$ \\
\hline
\end{tabular}




\begin{tabular}{|c|c|c|c|}
\hline Gender & $\begin{array}{l}\text { feminine } \\
\text { masculine } \\
\text { Total } \\
\text { no data } \\
\text { Total }\end{array}$ & \begin{tabular}{|l|}
95 \\
75 \\
170 \\
5 \\
175
\end{tabular} & $\begin{array}{l}54,3 \\
42,9 \\
97,1 \\
2,9 \\
100,0\end{array}$ \\
\hline Income & $\begin{array}{l}\text { Up to } 10,000 \\
10,000 \text { to } 30,000 \\
30000 \text {, to } 60,000 \\
\text { Total } \\
\text { missing value } \\
\text { Total }\end{array}$ & $\begin{array}{l}15 \\
90 \\
55 \\
160 \\
15 \\
175\end{array}$ & $\begin{array}{l}8,6 \\
51,4 \\
31,4 \\
91,4 \\
8,6 \\
100,0\end{array}$ \\
\hline Education & $\begin{array}{l}\text { metric } \\
\text { intermediate } \\
\text { graduate } \\
\text { master } \\
\text { Total }\end{array}$ & \begin{tabular}{|l|}
10 \\
20 \\
140 \\
5 \\
175
\end{tabular} & \begin{tabular}{|l}
5,7 \\
11,4 \\
80,0 \\
2,9 \\
100,0
\end{tabular} \\
\hline
\end{tabular}

\section{Descriptive information about respondents}

\section{THE EMPIRICAL STAGE}

We analyzed mainly the textual part of advertising messages and investigated it from the pragmatic perspective. Many pragmatic aspects are to be taken into consideration when we speak about efficiency of advertising discourse: the pragmatic act (namely, the message hidden behind the uttered words), the context or the situational context of the dialogue, the discourse register (which indicates the technical aspects of the information), the type of verbal acts (which may indicate the illocutionary component of the message), the type of verbal interaction (which highlights the relationship established between interlocutors, namely the advertiser and the consumer), the levels of building a conversation, the discourse 
vectors, the principles of communication (whether they are kept or broken and why) [Reboul \& Moeschler, 2001].

\subsection{Data analysis}

\subsubsection{Quantitative data analysis}

To check the reliability of obtained data Cronbach's $\alpha$ was used which showed acceptable results for all the items.

\begin{tabular}{|c|c|c|}
\hline Dimension & Number of items & Cronbach's $\boldsymbol{\alpha}$ \\
\hline Power distance & 5 & .854 \\
\hline Collectivism & 6 & .699 \\
\hline Uncertainty avoidance & 5 & .697 \\
\hline Masculinity & 4 & .641 \\
\hline Long-term Orientation & 6 & .64 \\
\hline
\end{tabular}

Table 1. Reliability statistics for CVSCALE

\begin{tabular}{|c|c|c|}
\hline Dimension & Number of items & Cronbach's $\boldsymbol{\alpha}$ \\
\hline Power distance & 4 & .783 \\
\hline Collectivism & 7 & .691 \\
\hline Uncertainty avoidance & 3 & .704 \\
\hline
\end{tabular}

Table 2. Reliability statistics for FMCG

A Cultural values index was formed for each cultural dimension by averaging responses to the corresponding items [Naveen \& Yoo, 1998; Lenartowicz \& Roth, 1999]. The possible scores are represented in the range from 5 to 1 , where 5 is the maximum and 1 is the minimum.

\begin{tabular}{|c|c|}
\hline Dimension & Mean \\
\hline Power distance & 3.226 \\
\hline Collectivism & 3.009 \\
\hline Uncertainty avoidance & 4.013 \\
\hline
\end{tabular}




\begin{tabular}{|c|c|}
\hline Masculinity & 3.166 \\
\hline Long-term Orientation & 4.061 \\
\hline
\end{tabular}

Table 3. Cultural values mean

If to compare with the scores provided by Hofstede's model where Russia scores 93 for power distance, on the individual level PDI is not so high with mean 3.226. Collectivism does not have a high score both in Hofstede's model (39) and by individual level 3.009. According to Hofstede's model Uncertainty avoidance and Long term orientation have pretty high score with 95 and 81 respectively. The same high result they are getting on the individual level with means 4.013 and 4.061. When it comes to the analysis of collectivism and masculinity, both dimensions have low index - according to Hofstede, Masculinity scores 36, and Collectivism scores 39. On the individual level the mean for Masculinity is 3.166 and 3.009 for collectivism.

If to take into consideration that the perception of the level of adaptation by customers was measured by the Likert scale with the range from 1 to 5 , where 1 is strongly disagree and 5 is strongly agree, the results obtained after the conducted questionnaire analysis show that overall adaptation of international brands is average.

\begin{tabular}{|c|c|c|}
\hline Dimension & FMCG & Household appliances \\
\hline & Mean & Mean \\
\hline PDI & 2.077 & 2.179 \\
\hline UAI & 3.046 & 2.884 \\
\hline Col & 3.211 & 3.457 \\
\hline
\end{tabular}

\section{Table 4}

When analyzing purchase of FMCG only three cultural dimensions were taken into consideration. They were chosen based on the research conducted by de Mooje. These dimensions are Power distance, Uncertainty avoidance and Collectivism [Mooij, 2003].

The mean of coefficient concerning products which were used as a mediator for the analysis differs greatly from the mean of the dimensions on the personal level. If to compare means for power distance index for household appliances, it's a little bit higher than for the FMCG, which indicates that, though Russia is a country with relatively high PDI, it does not play a great role for analyzed goods. When it comes to the uncertainty avoidance index, it's higher for FMCG, which indicates that consumers are pretty stable in their choice of FMCG and loyal to the brands they are using. The index of Collectivism for both industries is higher when it comes to the industries we are analyzing than in overall individual level.

It was supposed that there is a significant relationship between cultural dimensions chosen for the analysis and the marketing strategy adaptation.

Adaptation is a dependent variable impacted by cultural dimensions as independent variables. The relationships were assessed first using correlation coefficients, which served as a preliminary test. 


\begin{tabular}{|c|c|c|c|c|c|}
\hline & & $\begin{array}{l}\text { adaptatio } \\
\mathrm{n}\end{array}$ & FPDI & FUAI & FCOL \\
\hline \multirow[t]{3}{*}{$\begin{array}{l}\text { adaptatio } \\
\mathrm{n}\end{array}$} & $\begin{array}{l}\text { Pearson } \\
\text { Correlation }\end{array}$ & 1 &,- 140 &,$- 545^{* *}$ &,$- 219^{* *}$ \\
\hline & Sig. (2-tailed) & & ,065 &, 000 &, 004 \\
\hline & $\mathrm{N}$ & 175 & 175 & 175 & 175 \\
\hline \multirow[t]{3}{*}{ FPDI } & $\begin{array}{l}\text { Pearson } \\
\text { Correlation }\end{array}$ &,- 140 & 1 &, $253^{* *}$ &, 085 \\
\hline & Sig. (2-tailed) &, 065 & &, 001 & ,261 \\
\hline & $\mathrm{N}$ & 175 & 175 & 175 & 175 \\
\hline \multirow[t]{3}{*}{ FUAI } & $\begin{array}{l}\text { Pearson } \\
\text { Correlation }\end{array}$ &,$- 545^{* *}$ &, $253^{* *}$ & 1 &, $149^{*}$ \\
\hline & Sig. (2-tailed) &, 000 &, 001 & &, 049 \\
\hline & $\mathrm{N}$ & 175 & 175 & 175 & 175 \\
\hline \multirow[t]{3}{*}{ FCOL } & $\begin{array}{l}\text { Pearson } \\
\text { Correlation }\end{array}$ &,$- 219^{* *}$ & ,085 &, $149^{*}$ & 1 \\
\hline & Sig. (2-tailed) &, 004 & ,261 &, 049 & \\
\hline & $\mathrm{N}$ & 175 & 175 & 175 & 175 \\
\hline
\end{tabular}

*. Correlation is significant at the 0.05 level (2-tailed).

**. Correlation is significant at the 0.01 level (2-tailed).

\section{Table 5. Correlation of adaptation and cultural dimensions}

The results of correlation prove that there is a significant level of correlation between uncertainty avoidance index and adaptation, and collectivism and adaptation of international brands. As for both these dimensions, the correlation is negative because the correlation index is negative. It means that as one variable increases in value, the second variable decreases in value. Power distance index, though having negative coefficient, does not show any statistical significance. After this, hypotheses were tested by linear regression. 


\begin{tabular}{|l|l|l|l|l|}
\hline $\begin{array}{l}\text { Mode } \\
1\end{array}$ & $\mathrm{R}$ & $\begin{array}{l}\mathrm{R} \\
\text { Square }\end{array}$ & $\begin{array}{l}\text { Adjusted R } \\
\text { Square }\end{array}$ & Std. Error of the Estimate \\
\hline 1 &, $562^{\mathrm{a}}$ &, 316 &, 304 &, 56031 \\
\hline
\end{tabular}

a. Predictors: (Constant), FCOL, FPDI, FUAI

\section{Table 6. Linear regression Model Summary}

The output's first table shows the model summary and overall fit statistics. We find that the adjusted $\mathrm{R}^{2}$ of our model is 0.304 with the $\mathrm{R}^{2}=.316$ that means that the linear regression explains $31.6 \%$ of the variance in the data.

\begin{tabular}{|c|c|c|c|c|c|c|}
\hline & Model & $\begin{array}{l}\text { Sum of } \\
\text { Squares }\end{array}$ & df & $\begin{array}{l}\text { Mean } \\
\text { Square }\end{array}$ & F & Sig. \\
\hline \multirow[t]{3}{*}{1} & $\begin{array}{l}\text { Regressio } \\
\mathrm{n}\end{array}$ & 24,794 & 3 & 8,265 & 26,325 &, $000^{\mathrm{a}}$ \\
\hline & Residual & 53,686 & 171 & ,314 & & \\
\hline & Total & 78,480 & 174 & & & \\
\hline
\end{tabular}

a. Predictors: (Constant), FCOL, FPDI, FUAI

b. Dependent Variable: adaptation

\section{Table 7. Linear regression ANOVA}

The Coefficients table first shows the constant and the regression coefficients (b) for each explanatory variable. The constant value (4.613) represents the intercept. The next values here are the regression coefficients for FPDI which is equal to .005, the regression coefficients for FUAI which is equal to -.465 and the regression coefficients for FCOL which is equal to .105 .

\begin{tabular}{|c|c|c|c|c|c|c|}
\hline & \multirow[b]{2}{*}{ Model } & \multicolumn{2}{|c|}{$\begin{array}{l}\text { Unstandardized } \\
\text { Coefficients }\end{array}$} & \multirow{2}{*}{$\begin{array}{c}\begin{array}{c}\text { Standardized } \\
\text { Coefficients }\end{array} \\
\text { Beta }\end{array}$} & \multirow[b]{2}{*}{$\mathrm{t}$} & \multirow[b]{2}{*}{ Sig. } \\
\hline & & B & Std. Error & & & \\
\hline \multirow[t]{4}{*}{1} & Constant & 4,613 & ,232 & & 19,857 & ,000 \\
\hline & FPDI &, 005 &, 064 &, 005 & 079 &, 937 \\
\hline & FUAI &,- 465 &, 058 &,- 525 & $-7,959$ &, 000 \\
\hline & FCOL &,- 105 &, 048 &,- 141 & $-2,199$ &, 029 \\
\hline
\end{tabular}

a. Dependent Variable: adaptation

Table 8. Linear regression 
The Beta $(\beta)$ helps us judge about the relative importance of explanatory variables. From Beta $(\beta)$ coefficients we can see that the effect of UAI is larger relative to PDI and COL, as it can be seen by the relative difference in beta values (.005 versus -.525 and -.141 ).

But as we can see from the table the p-value for FPDI is larger than .05 so we can conclude that this variable is statistically not significant.

There is a significant relationship between the level of collectivism of Russian consumers and marketing strategy adaptation (FMCG).

There is a significant relationship between the level of uncertainty avoidance of Russian consumers and marketing strategy adaptation (FMCG).

\subsubsection{Empirical data analysis}

For the empirical data analysis several advertisements by TNCs were chosen.

The first case of adaptation chosen for the analysis is the advertisement created by $P \& G$ for the Pantene shampoo. It was decided to compare the advert produced for the UK market and for the Russian market.

In the Russian version of the advertisement the main character, or the so called the guarantee of the brand is Evgenia Medvedeva, Olympic awardee in figure skating in 2018. It is very common to use a famous person for the advertisement in order to create a trustful image of the advertisement.

For the UK version Ellie Goulding, British singer and composer, was chosen as a guarantee. She produces a very strong and persuasive image.

\begin{tabular}{|c|c|}
\hline UK version & Russian version \\
\hline $\begin{array}{l}\text { I believe in strong. Strong is not just about } \\
\text { how hard you hit. Strong is pushing } \\
\text { yourself to your limit. And then realizing } \\
\text { you have no limit. Strong is banding and } \\
\text { not breaking. Strong is something that } \\
\text { comes from the inside. Where it counts } \\
\text { for you and your hair. Because when you } \\
\text { are strong in the inside you can do } \\
\text { anything. And that's a beautiful thing. } \\
\text { Strong is beautiful. }\end{array}$ & $\begin{array}{l}\text { Чтобы мои волосы были сильными, еще на } \\
\text { старте я заряжаю их силой. Представляем } \\
\text { самый большой прорыв пантин за } \\
\text { последние } 30 \text { лет. Новая формула про-ви } \\
\text { наполняет волосы питательными } \\
\text { элементами и делает их на } 100 \% \text { сильнее. } \\
\text { Пантин - сильный старт для твоих волос. } \\
\text { Красота в силе. }\end{array}$ \\
\hline
\end{tabular}

The message hidden behind the uttered words is obvious. For both Russia and the UK the marketers were trying to create an image of a strong woman, and this strong woman is using Pantene.

The slogan of the advert contains no more than 12 words, three for both versions. While the message included in the slogan differs. For the UK version "Strong is beautiful" enforces that if you are strong you are beautiful. While in the Russian version "Красота в силе" ("beauty is in the strength") puts the word beauty on the first place, underlining that the product is first of all for the beauty and only after that it has something to do with the strength. 
While talking about the body text, it also differs greatly. For the UK version strength is the key element. The word strong is repeated 7 times drawing a lot of attention to this particular characteristic. It does not mention shampoo, it only provokes feelings and successfully fulfill the AIDA principle (attention, intention, desire, action), namely to draw the attention of the public, to raise its interest in finding out more details about the promoted product/service, to make the public desire the respective product and finally to determine the consumer to take action (to purchase the product, Salavastru, 2003).

In the Russian version the word strong is repeated only 4 times. The message of the text body is very direct with no metaphorical meaning. It just talks about shampoo and its properties, using the first sentence to explain the existence of the main character in the advert.

The Russian version brings us only to the "Learn level", giving information about the product, while the UK version can bring customers to both "Like level" or "Do level" [Bonnange \& Chantal, 2010].

However, the situational context of two adverts is very different.

In the Russian version of the ad customers see Evgenia, whose name is marked with the asterisk at the bottom of the screen, which brings some doubts if she is really famous enough for such a big brand. Second, even though she is a figure skating sportsman, there is no ice, and she is not skating, on the contrary, she is wearing some pinkish clothes. This fact initially contradicts the idea of "strength" which was ingrained in the advert and the slogan.

The UK version is more successful in terms of the situational context. Ellie is boxing and playing drums. The marketers decided to use black and white colors which create a stronger and more aggressive image of a woman but still keeping her feminine and beautiful.

When talking about adaptation strategy for this product from the viewpoint of the cultural dimension theory, the advert fulfills its goal. According to the quantitative data analysis, the most influential cultural dimension for Russian customers is the Uncertainty avoidance. Thus, closing a Russian celebrity for the guarantee is approved from this point of view as well as giving the information about the shampoo and its properties. The advert gives some dates and numbers which may seem more trustful for the customers making the product more attractive.

The second case study was chosen from P\&G products as well. Gillette SkinGuard advertisement was compared for the Russian and the UK markets in order to see the adaptation.

\begin{tabular}{|l|l|}
\multicolumn{1}{|c|}{ UK version } & \multicolumn{1}{|c|}{ Russian version } \\
\hline $\begin{array}{l}\text { I've got that scurfy beard because when I } \\
\text { shave I got this awful red rash on my } \\
\text { neck. I couldn't shave for my brother's }\end{array}$ & Когда порезы и раздражения напрягают \\
wedding. Then my mate suggested this & абсолютно новый джилетт скин гард с \\
Gillette skin guard. The blue belt actually & инновационным протектором, который \\
guards my skin, helps stop that redness. & снижает давление на кожу и помогает \\
Gillette the best the man can get & предотвратить порезы и раздражения. \\
& Чтобы ты мог показать свое истинное \\
& лицо. Ведь лучше тебя мужчины нет. \\
\hline
\end{tabular}

Even though the marketers are advertising the same product Gillette SkinGuard, they use different tools to create an attractive image for the customers. 
For Russian market they have chosen famous footballer Alexander Golovin as an endorser. Despite the fact that they use his image, the guarantee neither speaks for himself nor shares his experience. The situational context is bringing customers to the topic which of football, which is very popular and exploited by many marketing campaigns.

First of all, marketers appeal to negative emotions of their customers trying to provoke the feeling of irritation which is familiar to many of them. This is an interrogative discourse without a question mark at the end. The marketers are enforcing the message "Do you want to feel like this? No?" Then comes the answer: the customer should try the product. Then follows the detailed explanation of how the product works, accompanied by the video which makes it even more convincing. As for Russian consumers in particular, it refers to high uncertainty avoidance index. The customer understands how it works, he/she trusts it.

The slogan in the Russian version "Ведь лучше тебя мужчины нет. Джилетт" ("there's nothing better for a man") implies that you are the best if you use the product, creating the image of uniqueness.

For the UK version the situation is a little bit different. For the guarantee a regular man is selected to highlight the idea that the problem is common and the solution is right there. Customers can see some episodes of his life and then, similarly to Russian version, a detailed explanation of how the product works is shown.

The situational context leads the customers through different moments of the guarantee's life again, underlining that it is a regular problem, and it can happen any time.

As for the slogan, it differs from the Russian version. "Gillette the best the man can get". According to this version the product is the best, not the man.

\section{CONCLUSION}

To sum it all up, in the contemporary world it is very important to choose a proper marketing strategy. It is always up to the company and its peculiarities whether to choose standardization or adaptation. A lot of factors should be taken into consideration, culture and language being of paramount importance.

This paper has assessed Russian national culture on the individual level and the attitude of the Russian customers towards the adaptation of the marketing strategy. It has been proved statistically that the most influential dimension of the Russian national culture is Uncertainty Avoidance.

Two cases have been analyzed as examples of marketing strategy adaptation for Pantene and Gillette advertising campaigns. The analysis of empirical material reveals that in both cases the marketers are taking into consideration high Uncertainty Avoidance index of the Russian customers and trying to make their message as trustful as possible. 


\section{REFERENCES}

1. Bălănescu, O. (2014). Pragmatic approach on advertising discourse. International journal of linguistics, literature and culture, (Linqua-IJLLC)PP, 1(1), pp.31-42.

2. Bonnange, C., \& Thomas, Ch. (2010). Don Juan sau Pavlov: Essai Sur La Communication Publicitaire. Le Seuil (in French).

3. Brierley, S. (2002). The advertising handbook. $2^{\text {nd }}$ edition. London; New York: Routledge; Taylor \& Francis Group.

4. Condry, J. (2010). The psychology of television. New York: Lawrence Press.

5. Dake, K. (1991). Orienting dispositions in the perception of risk: an analysis of contemporary worldviews and cultural biases. Journal of cross-cultural psychology, 22(1), 61-82.

6. Goddard, A. (2002). Limbajul publicitatii. Editura Polirom, Iasi (in French).

7. Hall, E.T. (1976). Beyond culture. New York: Anchor Press.

8. Hofstede, G.H. (2001). Culture's consequences: comparing values, behaviors, institutions, and organizations across nations, $2^{\text {nd }}$ edition. Sage Publications, Inc.

9. Kotler, P., \& Keller, K.L. (2009). Marketing management. New Jersey: Prentice Hall.

10. Magee, L. (2011). The meaning of meaning: alternative disciplinary perspectives. In B. Cope, M. Kalantzis \& L. Magee (Eds.). Towards a semantic web: connecting knowledge in academic research (35-79), Elsevier.

11. Lages, L.F., Abrantes, J.L., \& Lages, C.R. (2008). The STRATADAPT scale: a measure of marketing strategy adaptation to international business markets. International marketing review, 25(5), 584-600.

12. Lenartowicz, T., \& Roth, K.A. (1999). Framework for culture assessment. Journal of international business studies, 30, 781-798.

13. Lustig M.W., Koester J. (2010). Intercultural Competence: Interpersonal Communication Across Cultures.Pearson.

14. Majumdar, R. (2004). Product management in India. Prentice Hall India Pvt., Limited.

15. Mooij, M. de. (2003). Convergence and divergence in consumer behavior: implications for global advertising. International journal of advertising, 183-202.

16. Mooij, M. de, \& Hofstede, G. (2002). Convergence and divergence in consumer behaviour: implications for international retailing. Journal of retailing, 61-69.

17. Morgan, N.A., Kalekam, A., \& Katsikeas, C.S. (2004). Antecedents of export venture performance: a theoretical model and empirical assessment. Journal of marketing, 68, 90-108.

18. Naveen, D., \& Yoo, B. (1998). Cultural influences on service quality expectations. Journal of service research, 2(2), 178-186.

19. Reboul, A., \& Moeschler, J. (2001). Pragmatica azi. O noua stiinta a comunicarii. Editura Ehinox, Cluj, traducere Liana Pop (in French).

20. Verschueren, J. (2015). Pragmatics, linguistic. In J.D. Wright (Eds.). International encyclopedia of the social \& behavioral sciences. $2^{\text {nd }}$ edition (795-802), Elsevier.

21. White, R. (2000). Advertising. McGraw Hill Publishing Company; Cambridge: Cambridge University Press.

22. Wong, N.Y., Rindfleisch, A., \& Burroughs, J.E. (2003). Do reverse-worded items confound measures in cross-cultural consumer research? The case of the material values scale. Journal of consumer research, 30, 72-91.

23. What about Russia? Retrieved from http://geert-hofstede.com/russia.html (accessed: 15 May, 2020). 


\section{How to cite this article:}

Tikhomirova, A.N. (2020). A pragmatic approach to the analysis of marketing adaptation to Russian national culture. Professional Discourse \& Communication, 2 (2), 31-46. https://doi.org/10.24833/2687-0126-2020-2-2-31-46

(c) (1)

This work is licensed under a Creative Commons Attribution 4.0 International License 